\title{
PERANCANGAN INVERTER BERBASIS MIKROKONTROLER DSPIC30F4011 DENGAN FEEDBACK ARUS MENGGUNANKAN METODE KONTROL PROPORTIONAL RESONANT
}

\author{
Agysta Rama Prasetya *), Iwan Setiawan, dan Mochammad Facta \\ Departemen Teknik Elektro, Universitas Diponegoro \\ Jl. Prof. Sudharto, SH, Kampus UNDIP Tembalang, Semarang 50275, Indonesia \\ ${ }^{*}$ E-mail : agystarama@gmail.com
}

\begin{abstract}
Abstrak
Inverter merupakan perangkat yang paling umum digunakan sebagai konverter untuk mengubah arus searah ke arus bolakbalik. Contoh aplikasi inverter yang sering dijumpai adalah pada sistem photovolaic yang tersambung dengan grid dimana kualitas arus keluaran inverter sangat berpengaruh terhadap kualitas daya. Dibandingkan dengan inverter dengan SPWM open loop, inverter dengan kontrol arus memiliki beberapa keunggulan diantaranya respon sistem yang lebih cepat dan memiliki akurasi yang tinggi dalam pengontrolan. Dalam Penelitian ini, dirancang inverter satu fasa tipe Full Bridge dengan metode kontrol proportional resonant menggunakan mikrokontroler 16-bit dsPIC30F4011. Arus keluaran inverter di feedback menggunakan sensor arus ACS712-05B. Pengujian dilakukan dengan arus referensi 1-1,25 A serta tegangan masukan $30 \mathrm{~V}_{\mathrm{DC}}$ dan $50 \mathrm{~V}_{\mathrm{DC}}$. Hasil pengujian menunjukkan bahwa kontrol proportional resonant adalah kontroler yang cocok untuk digunakan sebagai pengendalian arus AC pada inverter satu fasa yang dirancang karena arus aktualya sudah mendekati arus referensinya hingga sekitar 3,5 A. Dari tegangan output yang kecil terjadi karena penyesuaian arus yang melewati beban resistif, drop tegangan, dan pembagi tegangan dari induktor. Pada pengujian nilai harmonisa tegangan maupun arus terendah terdapat pada variasi $30 \mathrm{~V}_{\mathrm{DC}}$ arus referensi 1 A yauitu sebesar $8 \%$, sedangkan yang tertinggi yaitu $22,5 \%$ pada variasi $50 \mathrm{~V}_{\mathrm{DC}}$ arus referensi $2,5 \mathrm{~A}$.
\end{abstract}

Kata kunci : Inverter, Kontrol Arus, Proportional Resonant, .dsPIC30F4011

\begin{abstract}
Inverter is the most commonly used device as a converter to convert direct current to alternating current. Application of inverter is often found in grid connected photovoltaic systems where power quality depends on output current quality. If it is compared to the open loop SPWM inverters, the current-controlled inverters have several advantages such as quick system response and high accuracy. In this Research, I designed single phase full bridge inverter with propotional resonant control method is designed by using 16-bit microcontroller dsPIC30F4011. The magnitude of the inverter output current is sensed by the ACS712-05B current sensor. The experimental test is carried out with a current reference range of 1 $3,5 \mathrm{~A}$ and variation of DC $30 \mathrm{~V}$ and $50 \mathrm{~V}$. The test result that the propotional resonant is suitable for controlling AC current because actual current is approaching the current reference around 3,5 A. However, something still need to be improve in next research which is the current ripples still occur because the value of the inductor filter is less appropriate. A small output voltage occur because current flowing throught the resistive load, the voltage drops, and their voltage divider from inductor. In harmonics testing on single phase full bridge inverter using 16-bit microcontroller dsPIC30F4011 show that the lowest voltage and current harmonics at variation $30 \mathrm{~V}_{\mathrm{DC}}$ current reference $1 \mathrm{~A}$ is $8 \%$, while the highest is $22.5 \%$ at variation $50 \mathrm{~V}_{\mathrm{DC}}$ current reference of $2.5 \mathrm{~A}$.
\end{abstract}

Keywords : Inverter, Current Control, Proportional Resonant, dsPIC30F4011

\section{Pendahuluan}

Penggunaan sumber daya terbarukan pada pembangkit listrik menjadi semakin penting. Hal ini dikarenakan peningkatan energi listrik dari hari ke hari semakin tinggi dan ketersediaan bahan bakar fosil sebagai bahan bakar utama pada pembangkit listrik konvensional semakin terbatas [1]. Salah satu penggunaan energi baru terbarukan sebagai pembangkit listrik adalah teknologi photovoltaic (PV). Teknologi PV semakin berkembang karena adanya dukungan dari pemerintah dan beberapa perusahaan untuk menyambungkan PV dengan grid [2]. Inverter merupakan perangkat utama yang digunakan untuk mengkonversi tegangan DC menjadi tegangan AC. Inverter sendiri dibagi menjadi 3 jenis yaitu jembatan penuh, setengah jembatan, dorong tarik (Push pull/centre Tapped load)[3]. Inverter 
jembatan penuh memiliki keuntungan, yaitu dapat diaplikasikan dengan daya yang besar, namun memiliki kerugian yaitu pada proses switchingnya, karena memiliki 4 saklar semikonduktor yang dioperasikan secara bergantian tanpa harus hubung singkat[4].

Pada penelitian ini telah dirancang sebuah inverter satu fasa dengan menggunakan sistem kendali mikrokontroller dsPIC30F4011. Pembangkitan sinyal SPWM dengan menggunakan dsPIC30F4011 ini lebih mudah dan ringkas karena mikrokontroler ini sudah langsung memiliki keluaran 6 output PWM, dan pembangkitan sinyalnya dilakukan melalui senarai program[5]. Selain itu dsPIC30F4011 memiliki kemampuan Digital Signal Processing [6] yang mampu memproses data secara cepat dan mempunyai lebar data 16 bit [7]. Inverter satu fasa yang dirancang ini jenis pemicuan SPWM berbasis mikrokontroller 16-bit dsPIC30f4011 dengan metode Proportional Resonant. Metode kotrol Propotional Resonant ini memberikan respon sistem cepat dan dapat mengikuti sinya referensi dengan baik. Pada inverter yang telah dibuat memiliki performa handal dengan efisiensi tinggi dan arus keluaran inverter dapat menyesuaikan referensi[8].

\section{Metode}

Gambar 1. merupakan blok diagram perancangan perangkat keras inverter satu fasa dengan kontroler arus Proportional Resonant. Perancangan ini terdiri beberapa blok utama yaitu blok suplai AC 1 fasa, rangkaian daya, rangkaian kontrol, sensor arus ACS712-05B, Digital to Analog Converter AD7302, dan blok beban. Pada rangkaian kontrol terdapat rangkaian mikrokontroler DSPIC30F4011 dan rangkaian driver MOSFET TLP250. Pada rangkaian daya terdapat full wave bridge rectifier sebagai sumber daya DC masukan inverter dan inverter satu fasa tipe Full Bridge.

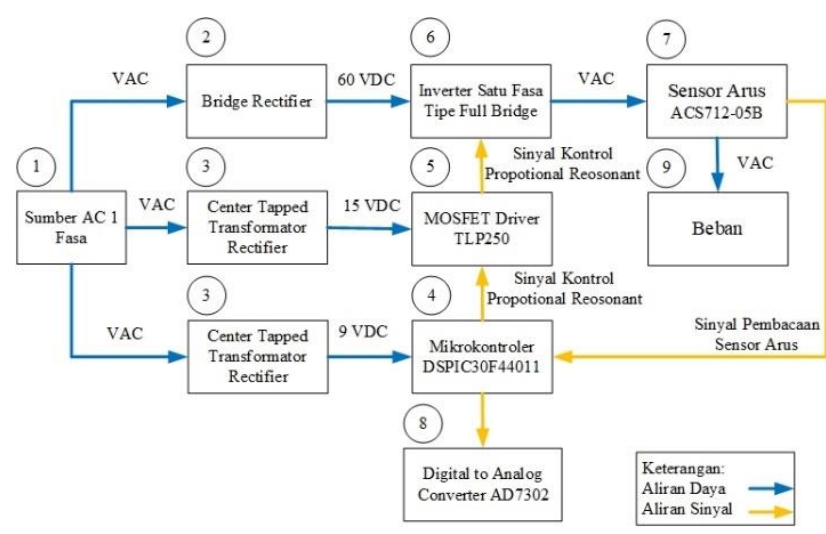

Gambar 1. Blok Diagram Perangkat Keras

Spesifikasi inverter satu fasa tipe full bridge berdasarkan Gambar 1. yang dirancang pada Penelitian ini dijelaskan sebagai berikut.
1. Sumber tegangan AC 1 fasa digunakan untuk mensuplai rangkaian daya dan rangkaian kontrol.

2. Suplai tegangan DC untuk rangkaian daya inverter diperoleh dari hasil penyearahan tegangan AC menggunakan bridge rectifier.

3. Suplai 15 V DC untuk rangkaian driver MOSFET dan mikrokontroler DSPIC30F4011 diperoleh dari hasil penyearahan tegangan AC keluaran trafo menggunakan center-tapped full wave rectifier.

4. Mikrokontroler 16-Bit DSPIC30F4011 digunakan untuk menghasilkan sinyal kontrol Proportional Resonant berdasarkan arus aktual yang terukur oleh sensor dan arus referensi yang diberikan. Arus referensi dihasilkan melalui pembacaan potensiometer melalui fasilitas ADC.

5. TLP250 digunakan sebagai MOSFET driver dengan suplai DC yang memiliki ground berbeda-beda pada sisi high inverter satu fasa.

6. Jenis inverter yang dirancang adalah inverter satu fasa tipe full bridge, yang terdiri dari empat buah MOSFET tipe IRF460.

7. Sensor arus ACS712-05B digunakan untuk mengukur arus keluaran inverter dan mengirim informasi berupa tegangan kepada mikrokonreoler DSPIC30F4011 melalui fasilitas ADC.

8. Digital-to-Analog Converter AD7302 digunakan untuk menampilkan tegangan keluaran yang merepresentasikan arus referensi dan arus aktual yang diukur oleh sensor pada osiloskop.

9. Blok beban terdiri dari beban yang terhubung dengan keluaran inverter satu fasa. Beban yang digunakan dalam Penelitian ini adalah berupa resistor.

\subsection{MOSFET Driver TLP250}

Rangkaian MOSFER DRIVER TLP 250 digunakan untuk mengisolasi dan menguatkan sinyal kontrol proportional resonant dengan level tegangan 5 Volt yang dibangkitkan dsPIC30f4011 menjadi level tegangan yang lebih tinggi dengan sistem ground terpisah (level tegangan $15 \mathrm{~V}$ ) dan cukup untuk memicu MOSFET (Metal Oxide Semiconductor Field Effect Transistor) sebagai driver. [17].

MOSFET sisi atas (high-side) terhubung dengan optocoupler yang memiliki suplai DC terpisah dengan fasa lain dan MOSFET Driver sisi low, sedangkan MOSFET pada sisi bawah (low-side) terhubung dengan rangkaian optocoupler yang memiliki titik referensi ground yang sama dengan MOSFET Driver sisi low pada fasa yang lain [17]. 


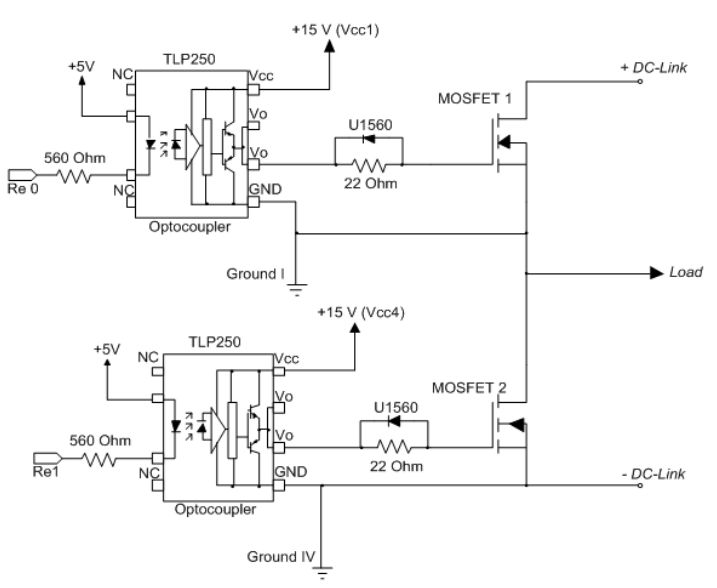

Gambar 2. Rangkaian MOSFET Driver TLP250

\subsection{Sensor Arus ACS712-05B}

Sensor arus ACS712-05B digunakan sebagai perangkat pengukuran dan pembacaan nilai arus aktual yang melalui beban dalam Penelitian ini. Sensor ini bekerja dengan prinsip hall effect. Arus yang mengalir melewati sensor akan dibaca dan dikonversikan menjadi nilai tegangan yang proporsional, kemudian sinyal berupa tegangan tersebut akan dibaca oleh modul ADC pada mikrokontroler DSPIC30F4011.

Tegangan keluaran sensor akan bernilai sekitar 2,5 V saat tidak ada arus yang mengalir melewati sensor. Berdasarkan datasheet, sensitivitas sensor arus ACS712-05B ini adalah sebesar $185 \mathrm{mV} / \mathrm{A}$ [6], namun jenis sensor yang digunakan sudah dilengkapi IC op-amp atau penguat sinyal TLC2272ACD yang dapat digunakan untuk mengatur nilai offset dan gain melalui dua potensiometer yang dihubungkan pada IC op-amp tersebut. Potensiometer gain diatur hingga nilai sensitivitas sensor berubah menjadi 0,5 V/A, sehingga nilai tegangan keluaran maksimal dari sensor saat arus yang terbaca sebesar 5 A sesuai dengan Persamaan 1 berikut.

$$
\begin{aligned}
& V_{\text {out }}=2,5+0,5 \cdot i \\
& V_{\text {out }}=2,5+0,5 \cdot 5 \\
& V_{\text {out }}=5 \mathrm{~V}
\end{aligned}
$$

Tegangan keluaran sensor diatur menjadi maksimal $5 \mathrm{~V}$ untuk memudahkan pembacaan oleh modul analog-todigital converter yang memiliki tegangan referensi sebesar $5 \mathrm{~V}$.

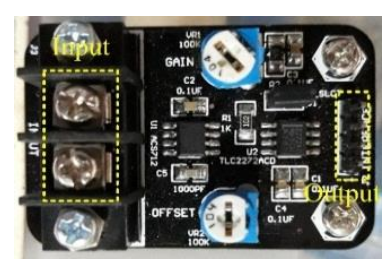

Gambar 3. Sensor Arus ACS712-05B

\subsection{Inverter Satu Fasa dengan Kontrol Arus Proportional Resonant}

Kontrol Proportional Resonant adalah salah satu sistem kontrol loop tertutup yang mampu untuk memperbaiki respon sistem. Seperti diketahui output frekuensi dari inverter yang dikehendaki adalah $50 \mathrm{~Hz}$. Tujuan dari kontroler ini adalah untuk mengontrol variabel sinusoidal yang memiliki frekuensi resonansi di $50 \mathrm{~Hz}$ dan di saat yang sama menolak frekuensi yang lain [2]. Berikut adalah transformasi Laplace dari kontroler PR secara ideal [1]:

$$
G_{P R}(s)=K_{p}+\frac{2 K_{r} s}{s^{2}+\omega_{1}^{2}}
$$

Di mana $K_{p}$ adalah gain proporsional, $\omega_{1}$ adalah frekuensi resonan, dan $K_{r}$ adalah gain resonan. Kontroler PR memberikan gain tak terhingga pada frekuensi tertentu (frekuensi resonan) dan nol pergeseran fasa. Namun, kontroler ini tidak mampu merealisasikan rangkain sirkuit fisik tanpa rugi, dan bentuk kontroler yang diperbaiki adalah alternatif praktisnya [1].

Untuk mengumpan balikkan nilai keluaran arus dari inverter dengan mengontrol variabel sinusoidal yang memiliki frekuensi resonansi di $50 \mathrm{~Hz}$ maka digunakanlah sinyal kontrol proportional resonant. Nilai error $e(t)$ diperoleh dari hasil pengurangan nilai arus aktual yang diukur oleh sensor arus $(y)$ dan nilai referensi arus yang diberikan lewat potensiometer $(u)$. Setelah mendapatkan nilai $e(t)$, kontroler akan menghitung nilai error dengan nilai penguatan untuk menghasilkan sinyal kontrol.

Berikut adalah persamaan kontroler proportional resonant dalam bentuk transformasi Laplace yang ditunjukkan pada Persamaan 3 [1]:

$G_{P R}(s)=K_{p}+\frac{2 K_{r} \omega_{P R c} s}{s^{2}+2 \omega_{P R c} s+\omega_{1}^{2}}$

Tiga parameter yang dibutuhkan untuk kontroler PR adalah sebagai berikut[15]:

- $\omega_{P R c}$ untuk menyesuaikan bandwidth di sekitar frekuensi resonan.

- $K_{p}$ untuk mendapatkan respon transient yang cepat dan kestabilan yang bagus.

- $K_{r}$ untuk menghilangkan steady-state error fasa dan magnitude.

- $\omega_{1}$ adalah frekuensi resonan.

\subsection{Total Harmonic Distortion Pada Inverter Satu Fasa Berbasis Mikrokntroller dsPIC30F4011}

Pengujian THD (Total Harmonic Distortion) dilakukan untuk mengetahui nilai harmonisa pada rangkaian inverter full-bridge berbasis mikrokontroller dsPIC30F4011 terhadap nilai THD pada gelombang tegangan dan arus keluarannya. Nilai THD tegangan dan arus ini didapatkan dari Power Quality Analizyer dengan jumlah orde sebesar 25. Gambar 4 merupakan rangkaian pengujian THD pada 
rangkaian inverter full-bridge berbasis mikrokontroller dsPIC30F4011.

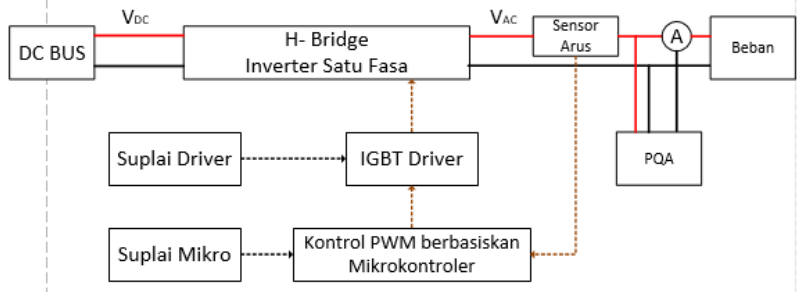

Gambar 4. Skema Rangkaian Pengujian THD pada Keluaran Inverter

Total Harmonic Distortion (THD) adalah perbandingan antara nilai RMS dari seluruh komponen harmonisa terhadap nilai RMS dari fundamental. THD biasanya dinyatakan dalam bentuk persentase (\% THD).

Nilai THD ini akan digunakan untuk mengukur besarnya penyimpangan dari bentuk gelombang periodik yang mengandung harmonisa dari gelombang sinusoidal murninya. Untuk gelombang sinusoidal sempurna nilai THD-nya adalah 0\%, sedangkan untuk menghitung THD dari arus dan tegangan yang mengalami distorsi adalah dengan menggunakan Persamaan 4 dan 5:

$$
V_{T H D}=\frac{\sqrt{\sum_{n=2}^{\infty} V_{n}^{2}}}{V_{1}} \quad \mathrm{X} 100
$$

Dimana:

$V_{n}=$ Nilai tegangan harmonisa $(\mathrm{V})$

$V_{l}=$ Nilai tegangan fundamental $(\mathrm{V})$

$n$ = komponen harmonisa maksimum yang diamati

$$
I_{T H D}=\frac{\sqrt{\sum_{n=2}^{\infty} I_{n}{ }^{2}}}{I_{1}} \times 100 \%
$$

Dimana:

$I_{n}=$ Nilai arus harmonisa $(\mathrm{A})$

$I_{l}=$ Nilai arus fundamental $(\mathrm{A})$

$n=$ komponen harmonisa maksimum yang diamati.

\section{Hasil dan Analisis}

3.1. Pengujian Gelombang Keluaran Rangkaian Kontrol

\subsubsection{Pengujian Gelombang Keluaran DSPIC30F4011}

Pengujian dilakukan untuk memastikkan bahwa modul PWM pada DSPIC30F4011 dapat membangkitkan sinyal kontrol dalam mode komplementer dengan adanya dead time sebesar $1 \mathrm{uS}$ antara pin PWMxL dan PWMxL.
Pengujian dilakukan dengan program PWM open loop dengan frekuensi PWM $20 \mathrm{kHz}$.

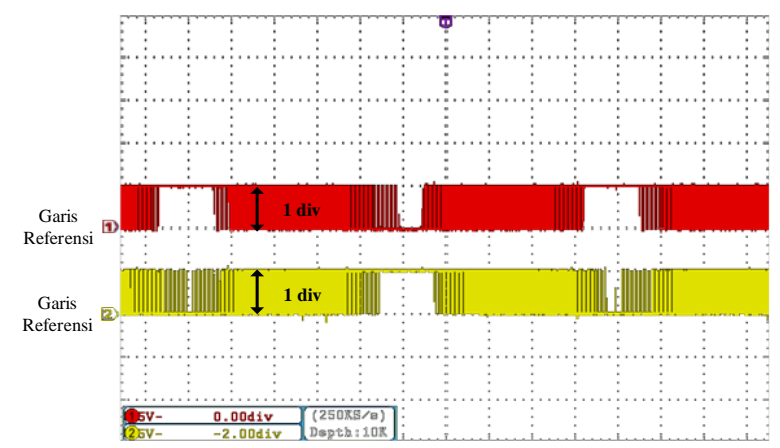

Gambar 5. Gelombang Keluaran PWM Open Loop

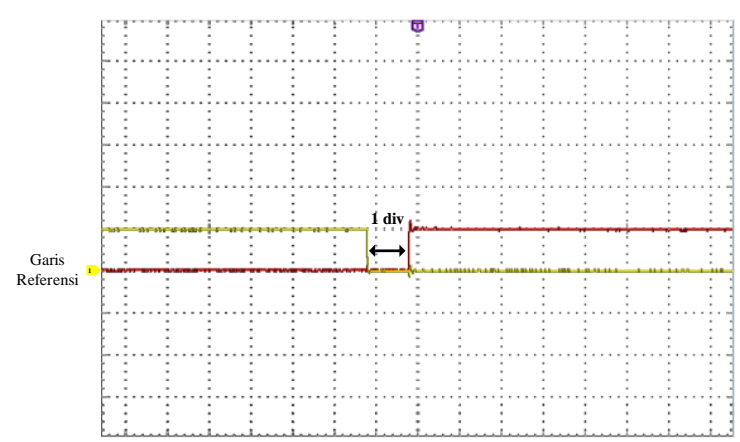

Gambar 6. Dead Time pada Keluaran PWM Open Loop

Hasil pengujian keluaran DSPIC30F4011 pada SPWM open loop menunjukkan bahwa sinyal kontrol bekerja dalam mode komplementer serta adanya dead time sebesar $1 \mathrm{uS}$ antara PWM sisi high dan PWM sisi low.

\subsubsection{Pengujian Gelombang Keluaran MOSFET Driver TLP250}

Pengujian pada rangkaian ini dilakukan untuk mengetahui dan memastikan gelombang tegangan keluaran dari MOSFET driver TLP250 telah sesuai dengan perancangan dan dapat digunakan untuk pemicuan MOSFET.

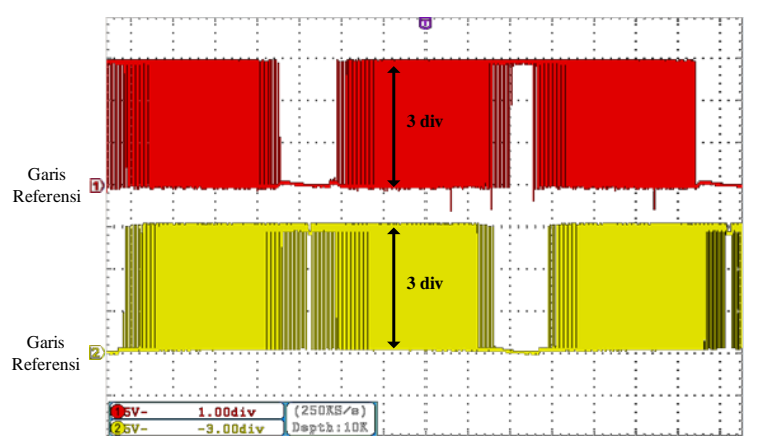

Gambar 7. Gelombang Keluaran Driver MOSFET TLP250

Hasil pengujian gelombang keluaran dari MOSFET driver TLP250 telah sesuai dengan perancangan dan dapat digunakan untuk memicu MOSFET. 


\subsection{Pengujian Sensor Arus ACS712-05B}

Pengujian sensor arus ACS712-05B dilakukan dengan mengukur tegangan keluaran sensor yang telah dikalibrasi sebelumnya saat dialiri arus sebesar 1 A. Arus diberikan dengan cara memasang beban resistif secara seri dengan sumber tegangan AC yang diatur sedemikian rupa hingga nilai arus yang mengalir adalah $1 \mathrm{~A}$.

Nilai arus yang diukur oleh sensor direpresentasikan secara proporsional oleh tegangan keluaran sensor. Sebelumnya pada perancangan sensor arus telah diatur nilai offset tegangan keluaran sensor adalah $2,5 \mathrm{~V}$ dan sensitivitas pembacaan arus oleh sensor adalah 0,5 V/A.

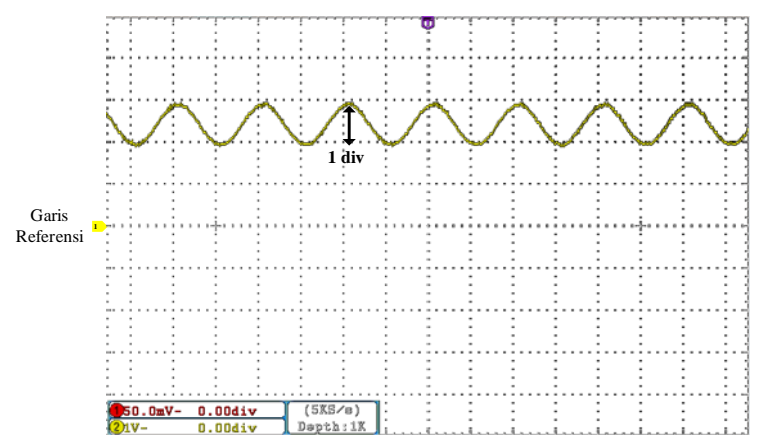

Gambar 8. Gelombang Keluaran Sensor Arus ACS712-05B (I $=\mathbf{1} \mathbf{A})$

Nilai tegangan puncak ke puncak pada pengujian sensor dalam Gambar 8 memiliki jumlah div 5 dengan skala V/div $=1 \mathrm{~V}$ dengan faktor pengali probe $1 \mathrm{x}$. Hal ini sudah sesuai dengan perancangan dimana saat arus $=1 \mathrm{~A}$ maka diperoleh tegangan keluaran sensor sebagai berikut.

$$
\begin{aligned}
& V_{\text {out }}=2,5+0,5 \cdot i \\
& V_{\text {out }}=2,5+0,5 \cdot 1 \\
& V_{\text {out }}=3 \mathrm{~V}
\end{aligned}
$$

\subsection{Pengujian Keluaran Inverter Satu Fasa dengan SPWM Open Loop}

Pengujian ini dilakukan untuk mengetahui bentuk Pengujian bertujuan untuk mengamati bentuk gelombang dan magnitude tegangan keluaran inverter satu fasa yang dipicu oleh SPWM open loop. DC Bus yang diberikan yaitu $50 \mathrm{~V}_{\mathrm{DC}}$ dengan arus referensi $1 \mathrm{~A}$ dan 2,5 $\mathrm{A}$ menggunakan beban $12 \Omega$. Arus keluaran inverter tidak diumpan-balikkan pada sistem.

Berdasarkan gambar 9 dan gambar 10 dapat dilihat bahwa hasil pengujian tegangan keluaran inverter open loop pada tegangan DC Bus $50 \mathrm{~V}_{\mathrm{DC}}$. Pada gambar 9 nilai arus aktualnya sebesar 0,3 A sedangkan pada gambar 10 nilai arus aktualnya sebesar 0,5 A. Nilai yang kecil ini menunjukkan bahwa gelombang arus aktual belum mencapai referensi dengan baik. Hal ini disebabkan oleh tidak adanya penguatan kontrol

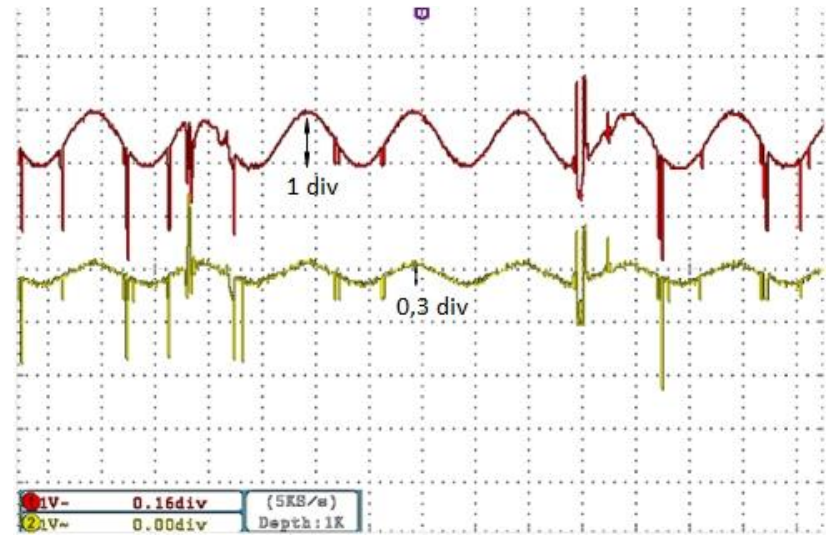

Gambar 9. Perbandingan Arus Referensi 1 A dengan Arus Aktual Menggunakan Beban 12 Ohm Pada Tegangan Input $50 \mathrm{~V}_{\text {DC }}(\mathrm{t} / \mathrm{div}=5 \mathrm{~ms})$.

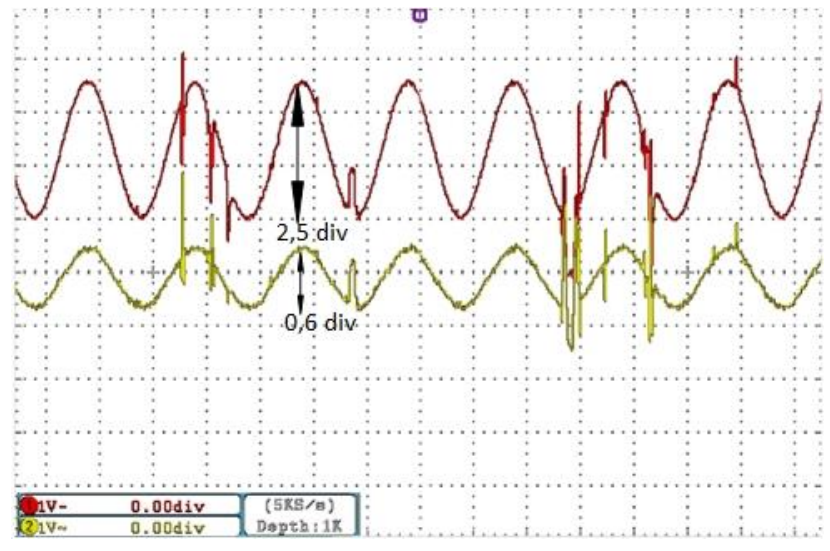

Gambar 10. Perbandingan Arus Referensi 2,5 A dengan Arus Aktual Menggunakan Beban 12 Ohm Pada Tegangan Input $50 \mathrm{~V}_{\text {DC }}(\mathrm{t} / \mathrm{div}=5 \mathrm{~ms})$.

\subsection{Pengujian Keluaran Inverter Satu Fasa dengan Kontrol Arus Proportional}

Pengujian bertujuan untuk mengamati bentuk gelombang dan magnitude arus keluaran inverter satu fasa yang dipicu oleh sinyal kontrol Proportional. Arus keluaran diamati melalui tegangan keluaran DAC. Tegangan DAC tersebut merepresentasikan referensi arus dan arus aktual secara proporsional.

DC Bus yang diberikan adalah sebesar $50 \mathrm{~V}_{\mathrm{DC}}$ dengan arus refereni sebesar $1 \mathrm{~A}$ dan 2,5 A. Arus keluaran inverter diumpan-balikkan pada mikrokontroler DSPIC30F4011. Hasil pengujian arus keluaran inverter kontroler arus Proportional pada beban $12 \Omega$.

Gambar 11 dan Gambar 12 menunjukkan hubungan arus keluaran inverter (kuning) dan referensi arus yang dibangkikan (biru). Hasil pengujian arus keluaran inverter dengan kontrol Proportional pada DC Bus $50 \mathrm{~V}_{\mathrm{DC}}$. Pada Gambar 11 dan Gambar 12 menunjukkan bahwa arus 
keluaran dapat mengikuti referensi yang diberikan dikarenakan nilai gain pada kontroler cukup untuk mencapai referensi. Ripple arus yang terjadi karena nilai filter induktor yang kurang sesuai.

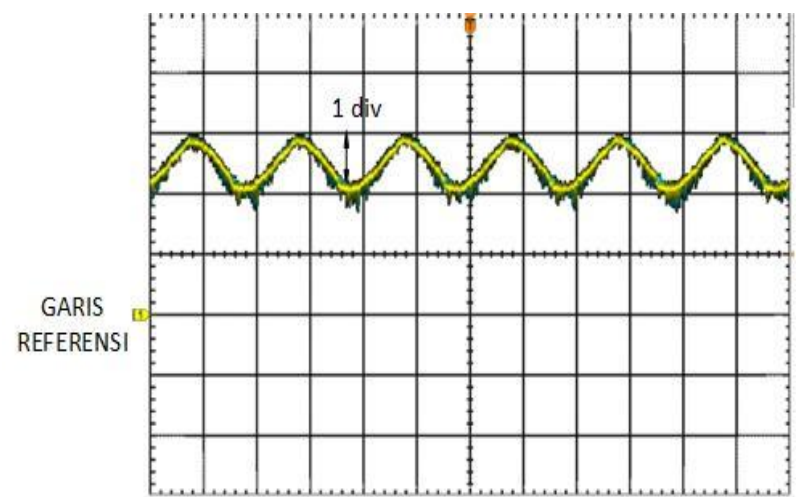

Gambar 11. Perbandingan Arus Referensi 1 A dengan Arus Aktual Menggunakan Beban 12 Ohm Pada Tegangan Input $50 \mathrm{~V}_{\text {DC }}$

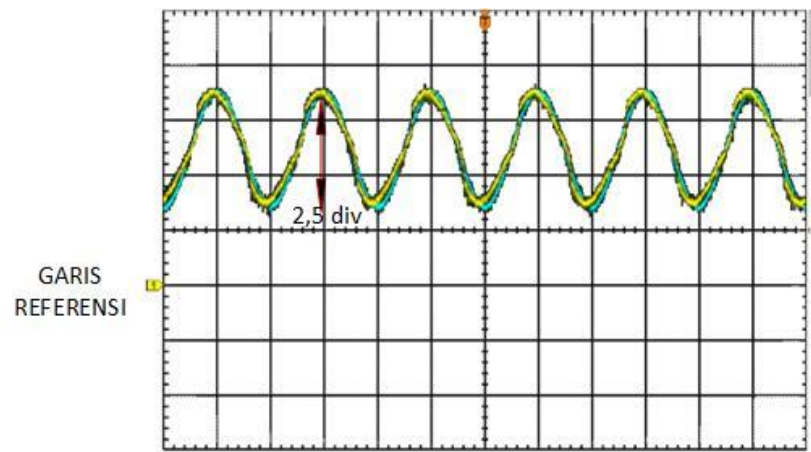

Gambar 12. Perbandingan Arus Referensi 2,5 A dengan Arus Aktual Menggunakan Beban 12 Ohm Pada Tegangan Input $50 \mathrm{~V}_{\text {DC }}$

\subsection{Total Harmonic Distortion (THD) Gelombang Tegangan dan Arus Harmonisa Keluaran Inverter Full-Bridge berbasis mikrokontroller dsPIC30F4011}

\subsubsection{Pengujian Total Harmonic Distortion (THD)}

pada Harmonisa Tegangan dan Arus Keluaran Inverter Berbasis Mikrokontroller dsPIC30F4011 Pada Tegangan DC Bus $50 \mathrm{~V}_{\mathrm{DC}}$

Pengujian Total Harmonic Distortion (THD) Pengujian THD (Total Harmonic Distortion) dilakukan untuk mengetahui nilai harmonisa pada rangkaian inverter fullbridge berbasis mikrokontroller dsPIC30F4011 terhadap nilai THD pada gelombang tegangan dan arus keluarannya. Nilai THD tegangan dan arus ini didapatkan dari Power Quality Analizyer dengan jumlah orde sebesar 25. Pengujian ini dilakukan dengan arus referensi 2,5A.

Berikut adalah tabel dari harmonisa tegangan dan arus keluaran dari inverter full-bridge berbasis mikrokontroller dsPIC40F3011 dengan arus referensi 2,5 A
Dari persamaan 4 dan 5 didapatkan hasil perhitungan dari $\mathrm{V}_{\mathrm{THD}}$.dan $\mathrm{I}_{\mathrm{THD}}$. Nilai dari $\mathrm{V}_{\mathrm{THD}}$ sebesar $22.653 \%$ dan $\mathrm{I}_{\mathrm{THD}}$ sebesar $21.933 \%$. Dari nilai harmonisa tegangan dan arus yang didapat maka dapat dibandingkan dengan hasil pengukuran. Berikut adalah hasil pengukuran harmonisa tegangan dan arus keluaran inveter full-bridge berbasis mikrokontroller dsPIC30F4011.

Tabel 1. Hasil Pegukuran Harmonisa Tegangan dan Arus Keluaran dari inverter full-bridge berbasis mikrokontroller dsPIC40F3011 Variasi Tegangan Input $50 \mathrm{~V}_{\mathrm{DC}}$ dan Arus Referensi 2,5 A dengan Menggunakan Beban $12 \mathrm{Ohm}$

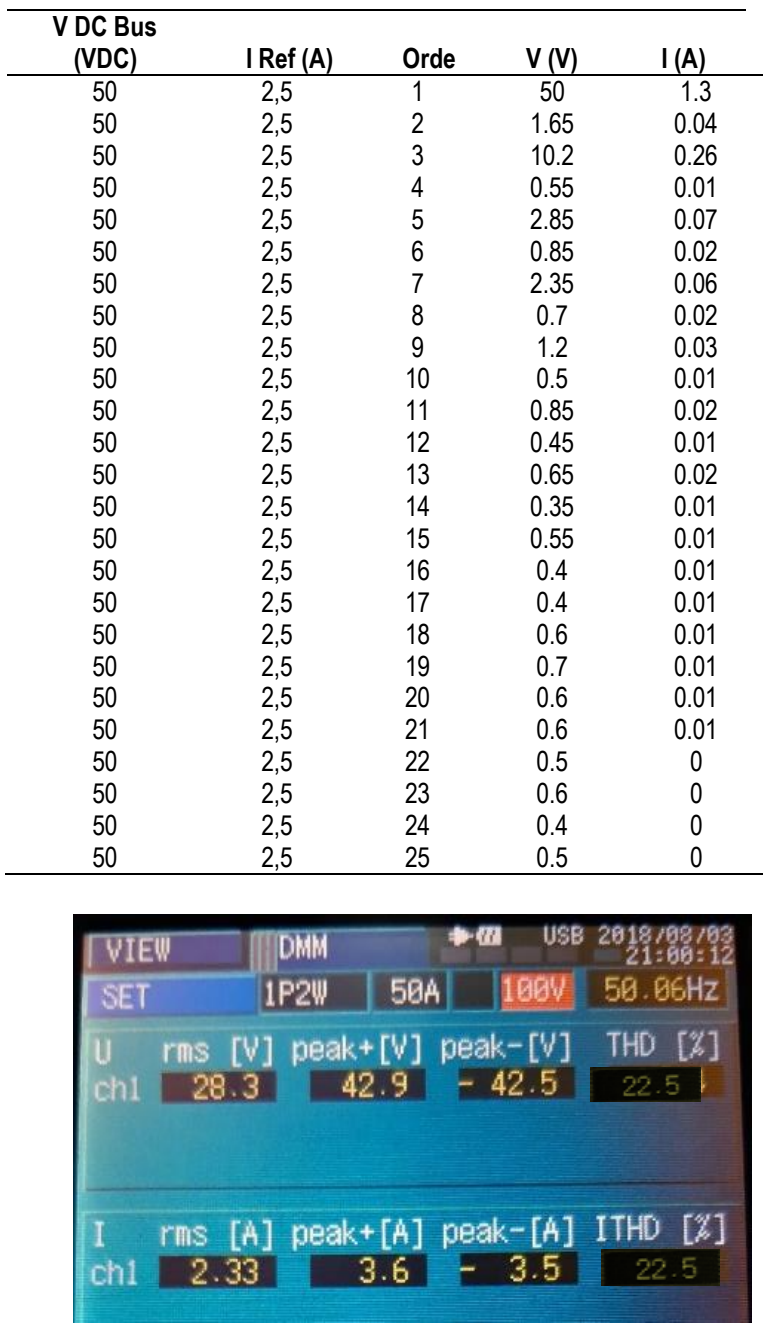

Gambar 13. Hasil Pengukuran Tegangan dan Arus Keluaran inveter dengan Tegangan Input 30V dan Arus Referensi 2,5A Menggunakan Beban 12 Ohm

Dari hasil perhitungan dan pengukuran harmonisa arus maupun tegangan keluaran inverter full-bridge berbasis mikrokontroller dsPIC40F3011 dapat dibuat tabel perbedaan antara harmonisa hitung dengan harmonisa arus sebagai berikut 
Tabel 2. Hasil Harmonisa Ukur, Hitung, dan Selisih Variasi DC Bus 50 VDC dan Arus Referensi 2,5 A

\begin{tabular}{|c|c|c|c|c|c|c|}
\hline $\begin{array}{l}\text { Harmo- } \\
\text { nisa }\end{array}$ & $\begin{array}{l}\text { Harmo- } \\
\text { nisa }\end{array}$ & $\begin{array}{l}\text { Selisih } \\
(\%)\end{array}$ & $\begin{array}{l}\text { Harmo } \\
\text {-nisa }\end{array}$ & $\begin{array}{l}\text { Harmo- } \\
\text { nisa }\end{array}$ & $\begin{array}{l}\text { Selisih } \\
(\%)\end{array}$ & \\
\hline Hitung & Ukur & & Hitung & Ukur & & \\
\hline Tegang & Tegang & & Arus & Arus & & [2] \\
\hline -an $(\%)$ & -an $(\%)$ & & $(\%)$ & $(\%)$ & & \\
\hline 22.653 & 22.5 & 0.153 & 21.933 & 22.5 & 0.567 & \\
\hline
\end{tabular}

Berdasarkan standar IEEE 519-1992, nilai maksimal yang diijinkan untuk THD-v maupun THD-i adalah 5\%. Hal ini menunjukkan bahwa nilai ukur THD-v dan THD-i pada DC Bus 30VDC arus referensi 1 A melebihi standar yang ditetapkan IEEE. Hal ini disebabkan tidak adanya filter yang menapis harmonisanya.

\section{Kesimpulan}

Inverter satu fasa SPWM telah berhasil direalisasikan dan dapat menghasilkan tegangan keluaran AC satu fasa terkontrol, dengan arus referensi yang dapat diatur. DsPIC30f4011 dapat digunakan dengan baik untuk menghasilkan gelombang pemicuan SPWM unipolar pada inverter satu fasa SPWM. Ripple arus yang terjadi karena nilai filter induktor yang kurang sesuai. Tegangan output pada beban resistif yang kecil terjadi karena arus yang melewati beban resistif kecil, drop tegangan pada keluaran inverter dan pembagi tegangan dari inductor karena dirangkai seri. Hasil pengujian dalam Penelitian ini menunjukkan bahwa kontrol proportional resonant adalah kontroler yang paling baik untuk digunakan sebagai pengendalian arus AC dibandingkan dengan kontrol openloop dan proportional.

\section{Referensi}

Zhang. Ningyun, "A Systematic Method for Designing a PR Controller and Active Damping of the LCL Filter for Single-Phase Grid-Connected PV Inverters", Energies, vol.7, pp. 3934-3954, 2014.

Aizam. Shamsul, "Comparison Study in Various Controller Single-Phase Inverters", IEEE SCORED, 2010.

S. Yuvarajan and H. L. Chiou, "A Novel Sine PWM Scheme Using Waveform Generators," IEEE Trans. Ind. Electron., vol. 41, no. 3, pp. 372-376, 1994.

[4]. S. W. Smith, Digital signal processing, 2nd ed. San Diego, California: California Technical Publishing, 1999.

[5]. M. T. Inc., DSPIC3OF4011/12 Data Sheet 16-Bit Digital Signal Controllers. 2010.

[6]. Daniel W Hart, Power Electronics, 2nd ed. New York: McGraw-Hill, 2011.

[7]. M. H. Rashid, POWER ELECTRONICS Academic Press Series in Engineering, 2001.

[8]. D. A. K. S. Anjana Thakur, "An Overview of Different PWM Techniques to Reduce Total Harmonic Distortion of Output in," Int. J. Recent Res. Electr. Electron. Eng., vol. 3, no. 2, pp. 65-69, 2016.

[9]. M. Tecnology Inc., "dsPIC30F Family Reference Manual," pp. 15-44, 2006.

[10]. Allegro, "Fully Integrated, Hall Effect-Based Linear Current Sensor IC with 2.1 kVRMS Isolation and a LowResistance Current Conductor", no. 16, pp. 1-16, 2017.

[11]. O. T. Way, "2.7 V to 5.5 V, Parallel Input Dual Voltage Output 8-Bit DAC," pp. 1-8, 1997.

[12]. I. Electronics, "DAC-08 Digital to Analog Converter," pp. 7-8, 2005.

[13]. Intersil, "Mur1540, mur1560, rurp1540, rurp1560.," no. 2778, pp. 1-4, 2000.

[14]. S. J. Al Achmad, I. Setiawan, and T. Andromeda, "Implementasi Kontrol Arus pada Inverter Satu Fasa Menggunakan dsPIC30F4011 Dengan Metode Kontrol Proportional Resonant," Universitas Diponegoro, Semarang, 2018.

[15]. A. Suryandi, "Studi Harmonisa Arus dan Tegangan Listrik Pada Kampus Politeknik Enjinering Indorama", Politeknik Enjinering Indorama, 2017 